\title{
"A Natureza é devido ao Homem, O Homem é o Fim da Natureza" LiÇÕES DE ANTROPOLOGIA DE IMmanuel Kant
}

\author{
Fernando M. F. Silva ${ }^{1}$ \\ (Centro de Filosofia da Universidade de Lisboa)
}

As seguintes peças, de que se dá abaixo tradução em língua portuguesa, compreendem todos os "Prolegómenos", "Proémios" ou "Capítulos introdutórios" aos cursos de Antropologia por Kant ministrados na Universidade de Königsberg entre 1772 e 1796 - designadamente, aqueles que até nós chegaram sob essa condição (1772-1789), e que hoje se encontram reunidos no volume 25 da Edição da Academia (AA 25) ${ }^{2}$. A estes juntamos, em nome de uma maior completude, e bem assim de uma mais ampla visão de conjunto de tal grupo de textos, duas outras versões de tais textos introdutórios: uma transcrita por Dohna Wundlacken, datada de $1790 / 91^{3}$, e uma outra transcrita por Friedrich Christian Starke, datada do mesmo ano académico ${ }^{4}$.

As Lições de Antropologia - assim nos dizem desassombradamente os próprios textos introdutórios aqui em apreço - constituem algo novo, até então intentado, na história do pensamento devotado ao Homem ${ }^{5}$.

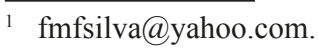

2 Kant (1900ff.), Gesammelte Schriften. Hrsg.: Bd. 1-22 Preussische Akademie der Wissenschaften, Bd. 23 Deutsche Akademie der Wissenschaften zu Berlin, ab Bd. 24 Akademie der Wissenschaften zu Göttingen. (AA)

3 Kant (1965), Die Philosophischen Hauptvorlesungen Immanuel Kants. Nach den neu aufgefundenen Kollegheften des Grafen Heinrich zu Dohna-Wundlacken, hrsg. Arnold Kowalewski, Hildesheim: Georg Olms Verlag.

4 Friedrich Christian Starke (1831), Immanuel Kants Anweisung zur Menschen- und Weltkenntnis, Leipzig, Die Expedition des Europäischen Aufsehers.

5 Segundo Kant, nascia com a Antropologia Pragmática uma nova forma de pensar o
}

Philosophica, 55-56, Lisboa, 2020, pp. 55-88. 
Com elas, diz Kant, deixava-se para trás toda uma plêiade de formas de fazer antropologia, e de estudar o humano - a saber, as antropologias metafísicas, fisiológicas, anatómicas, psicológicas etc., que sempre pautam a anterior (e por isso difusa) história da antropografia ${ }^{6}-$, e erigia-se um novo modo, por sinal pragmático, de observar o Homem na sua conduta e aplicação no Mundo. Assim vista, pois, como uma parte de uma doutrina do Mundo (Weltlehre) ${ }^{7}$, da qual a Geografia Física é pendant $^{8}$, a Antropologia Pragmática propõe-se inverter o tradicional método de abordar o humano, partindo não de princípios para fenómenos (causas para consequências), mas, pragmaticamente, de fenómenos para princípios (consequências para causas) ${ }^{9}$. Isto é, partindo da observação não meramente empírica, nem meramente racional, mas propriamente cosmológica $^{10}$ do Homem, extraindo da aplicação prudente do Homem no Mundo instruções para a condução do Homem segundo propósitos superiores, e por fim, em vista disto, obtendo princípios para a Metafísica, a Moral, a Religião ${ }^{11}$; princípios esses que, como tal, não são sem relação com a hábil racionalidade, e não são sem relação com a sábia moralidade, e portanto tão-pouco são desprovidos de benefício e de útil contributo

humano, e com esta nova concepção de humanidade, por um lado, uma nova ciência do humano (a Antropologia moderna, até então por fundar enquanto tal), por outro, uma nova disciplina académica (a Antropologia, ou Antropologia Pragmática, até então inexistente). Sobre isto, cf., entre outros exemplos, AA 25: 7 (Peça I); AA 25: 472 (Peça III); AA 25: 859 (Peça V).

6 Uma tal ambiguidade é patenteada nos próprios títulos de manuais de antropologia de tempos anteriores e contemporâneos de Kant, onde a Antropologia sempre surge difusamente entrelaçada com Medicina, Psicologia ou Fisiologia, entre outras ciências: a saber, Otto Casmann, Psychologia Anthropologica (1594); Riolan, Anthropographia et Osteologia (1618); Meisner, Anthropologia Sacra (1619); Kyper, Anthropologia Corporis Humanum (1647); Sperling, Synopsys Anthropologiae Physicae (1659); Hartmann, Anthropologiae Physico-Medico-Anatomicae (1696); Teichmeyer, Elementa Anthropologiae Sive Theoria Corporis Humani (1719); ou até Platner, Anthropologie für Ärtzte und Weltweisen (1772).

7 Cf. AA 25: 733.

8 Cf. AA 25: 9 (Peça I); AA 25: 470 (Peça III); AA 25: 733 (Peça IV).

9 Cf. AA 25: 735.

${ }^{10}$ Cf. AA 25: 734.

11 "O campo da Filosofia in sensu cosmopolitico deve ser reconduzido às seguintes questões: 1) O que posso eu saber? Isto é mostrado pela Metafísica. 2) O que devo eu fazer? Isto é mostrado pela Moral. O que posso eu esperar? Isto é ensinado pela Religião. 4) $\mathrm{O}$ que é o Homem? Isto é ensinado pela Antropologia. Os anteriores, poder-se-ia designá-los por Antropologia, na medida em que as três primeiras questões se referem à última." (AA 28.1: 533-534). 
para a boa promoção das mesmas. Assim propunha Kant toda uma nova concepção antropo-cosmológica de Homem e Mundo, a qual, à luz da anterior imagem tripartida, pode ser considerada uma terceira, intermédia dimensão do pensamento kantiano: uma dimensão que, em boa verdade, se insinuava já desde os primórdios da obra kantiana - desde a História Universal da Natureza e Teoria dos Céus (1755), ou as Observações sobre o Sentimento do Belo e do Sublime (1764) -, que justamente daria azo às Lições de Antropologia, e que por fim, qual veio multiforme, se estenderia a textos nos mais variados domínios do pensamento kantiano, como a História $^{12}$, a Política, a Educação $0^{13}$, a Estética ${ }^{14}$ ou a Moral.

Ora, uma tão pioneira criação, causando uma tão radical transformação no tecido epistemológico da época, assim como uma tão profunda transformação no pensamento de um autor, não poderia surgir sem mais - isto é, como se a Antropologia tivesse de ser pragmática, e tivesse de mediar as ciências metafísicas e as empíricas. Não. Com efeito, ela é não a origem, mas o fruto de uma longa gestação reflexiva kantiana sobre a mútua posição, objectivo e destinação das ciências no campo dos conhecimentos humanos; um período de árdua, por certo espinhosa reflexão do pensador Kant, ocorrido durante as décadas de 60 e 70, no qual a Antropologia desempenharia um importante papel, influenciando bem como sendo influenciada na recíproca definição das fronteiras e posições dos campos do saber humano. Um período que, por conseguinte, abordaremos abaixo em poucos traços.

Assim, notar-se-á por certo que, apesar de desde sempre conviver com um modo de pensar antropológico, ou cosmopolítico, este não viria

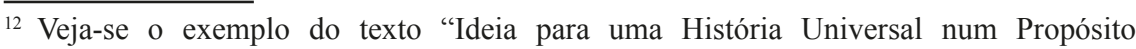
Cosmopolita" (1784), que é fruto visível das Lições de Antropologia de Kant. Não por acaso, as reflexões kantianas sobre a íntima relação entre Antropologia Pragmática e História, que se iniciam em 1775, em Anthropologie-Friedländer, 1775/76 (Peça III), têm o seu corolário teórico justamente em 1784/85, em Anthropologie-Mrongovius (Peça VI), onde Kant se refere a uma "história pragmática" (AA 25: 1212).

${ }^{13}$ Sobre o entretecimento de Política e Educação no plano cosmopolítico kantiano, e a inscrição destas e da sua acção conjunta na Antropologia, cf. não só o "Prooemium" de Anthropologie-Friedländer (Peça III), AA 25: 470, 472), mas também, no mesmo ano, e no mesmo conjunto de lições, a secção intitulada "Do Carácter da Humanidade em Geral" (AA 25: 675-697). Não por acaso, o tema é a partir de então retomado sem excepção nas Lições de Antropologia, como pode ser comprovado em AA 25: 734-735; AA 25: 858; AA 25: 1437.

${ }^{14}$ Estética que, enquanto Estética Natural, compõe a dita parte prática da Antropologia Pragmática de Kant (assim como uma dita Lógica Natural compõe a parte teorética da mesma). Sobre isto, cf. AA 24.1: 311, 318). 
expressamente à voz de Kant até bem tarde no decorrer da sua carreira. Aliás, até 1765, Kant não só considerava a Antropologia uma Psicologia Empírica - assim se inscrevendo entre tantos outros autores que mais tarde criticaria -, como afirmava que ambas se inscreviam no seio da Metafísica ${ }^{15}$; e mesmo quando rompe com as suas anteriores visões, dissociando a Psicologia Empírica da Metafísica ${ }^{16}$, e isso em lições expressamente ditas de Antropologia, em um curso de Antropologia por si inaugurado, porém, nem mesmo então - em 1772/73, Anthropologie-Collins e Parow - Kant dissocia ainda claramente a Antropologia Pragmática da Psicologia Empírica ${ }^{17}$. O mesmo, na verdade, é apenas corroborado por outras associações aparentemente inequívocas entre Psicologia Empírica e Antropologia Pragmática, discerníveis na Lição de Enciclopedística ${ }^{18}$, em várias Lições de Metafísica $^{19}$, em Lições de Lógica ${ }^{20}$, entre outros exemplos possíveis.

Ora, este até então apenas parcial processo de individuação da Antropologia Pragmática viria a ganhar no espírito de Kant uma decisiva inflexão - uma inflexão em parte motivada pela até então desconfortável e parcialmente incorrecta colocação da Antropologia no campo dos conhecimentos humanos, em parte só possível pela reconfiguração da Antropologia às mãos de outros terrenos do saber, onde Kant sempre a faria ressurgir. Pois, a partir da segunda metade da década de 70, e alicerçado sobre uma nova dicotomia - sistema (System) e agregado

15 Cf. o texto "Notícia da Disposição das suas Lições no Semestre de Inverno de 1765-1766", onde se diz: "Assim, começo após uma pequena introdução à Psicologia Empírica, que em rigor é a ciência metafísica da experiência dos homens." (AA 2: 309)

${ }^{16}$ Cf. AA 25: 8; AA 25: 243-244.

${ }^{17}$ Notar-se-á, aliás, que nos dois primeiros cursos de Antropologia até nós chegados, designadamente, Anthropologie-Collins e Anthropologie-Parow, ambos datados de 1772/73, Kant nunca chega a usar o termo "Antropologia", nem mesmo - o que, no nosso entender, não é fortuito - o termo "pragmática". Bem pelo contrário, em tais anos, Kant quase dá a entender que no seu espírito Antropologia se confunde ainda muito, ou é por completo, Psicologia Empírica (cf. AA 25: 244, quando Kant diz da Psicologia Empírica o que dirá exclusivamente da Antropologia em cursos posteriores; nomeadamente, que a Psicologia Empírica "merece também um curso particular", que ela "pode ser aprendida por todos" e que aí "se pode aprender as fontes de todas as acções humanas e o carácter dos homens na sua conexão". Só em 1775/76, em Anthropologie-Friedländer, e com a introdução da dicotomia sistema-agregado, este discurso se alterará radicalmente e a Antropologia Pragmática se afirmará na sua diferença em relação à Psicologia Empírica.

${ }^{18}$ Cf. AA 29.1: 10-12.

19 "Uma psicologia das observações pode ser designada uma antropologia" (AA 28.1.: 367). Cf. também AA 28.1: 175; AA 28.2: 541; AA 29.1: 750; AA 28.1: 367.

${ }^{20}$ Cf. AA 9: 15-18. 
(Aggregat) -, Kant propõe toda uma nova disposição dos saberes no campo dos conhecimentos humanos; a saber, uma redisposição perpendicular de todos os conhecimentos humanos, estendendo-se desde a "escada" das ciências metafísicas até ao "solo plano" ${ }^{21}$ das ciências históricas. A história exacta desta nova disposição, suas causas e sua necessidade, não é inteiramente clara. Mas dois factos parecem ser claros: em primeiro lugar, que ela parece estar já implantada, e servir para Kant como a divisão fundamental dos conhecimentos humanos, no ano lectivo de 1777/78 (disso nos dão prova a Lição de Enciclopedística ${ }^{22}$ e a Lição de Metafísica Pölitz I ${ }^{23}$, ambas desse ano, bem como as muito contestadas lições de Geografia Rink e Vollmer, que datam dessa altura ${ }^{24}$ ). Em segundo lugar, que, a partir do nada distante ano lectivo de 1775/76, mais concretamente o ano da lição de Antropologia-Friedländer, e mais ainda na posterior Lição Antropologia-Pillau (justamente de 1777/78), não só a dicotomia Agregado-Sistema surge pela primeira vez ${ }^{25}$, mas a ela agrega Kant várias outras dicotomias importantes na compreensão do seu pensamento, como as dicotomias de Escola e Mundo, ou escolasticismo e popularidade. Ora, do pensamento necessariamente conjunto de ambos estes factos parece emergir uma conclusão. A saber, que, durante parte da década de 70 - a dita década silenciosa - muito se diz porém, e explicitamente, sobre o processo de formação não só da Antropologia kantiana enquanto um sistema, mas da Antropologia Pragmática enquanto modo independente, mediador, de pensar os extremos que pautam a existência humana. Pois, note-se, aquando destes anos (1772-1777), e não por mero acaso, cresce em Kant a percepção de um hiato entre racional e empírico, entre teoria e prática, no campo dos conhecimentos humanos; e, ainda menos por acaso, a percepção de que teria de ser a Antropologia Pragmática a ocupar essa lacuna que se abre a partir do vértice do esquema perpendicular dos conhecimentos humanos. E, convicto disto mesmo, Kant sente a necessidade de, de uma assentada, libertar a Antropologia do jugo das ciências racionais, sem porém a lançar sem mais para o "solo plano" das

\footnotetext{
${ }^{21}$ Ambas as expressões, designadamente "Leiter" e "ebenen Boden", surgem em AA 28.1: 71.

22 Cf. AA 29.1: 5.

${ }^{23}$ Cf. AA 28.1: 171.

24 "Vorlesungen über Physische Geographie", in Friedrich Theodor Rink, Immanuel Kant's Physischer Geographie, Königsberg: Göbbels und Unzer, 1802, and "Geographie-Vollmer", in Johann J. W. Vollmer, Immanuel Kant, Physische Geographie, 4 vols., vol. 1.1, Mainz und Hamburg: Gottfried Vollmer, 1801-1805.

${ }^{25}$ O par dicotómico, de importância estruturante para Kant, surge pela primeira vez em Anthropologie-Friedländer (cf. AA 25: 470).
} 
ciências históricas; dir-se-ia pois, concedendo-lhe uma muito especial cientificidade (nem somente racional, nem somente empírica), e portanto também um muito especial lugar no amplo solo dos conhecimentos humanos. Isto faria Kant, primeiro, até 1772/73, libertando a Psicologia Empírica (e consequentemente a Antropologia) da Metafísica; mas depois, e mais fulcralmente, não inscrevendo por isso a Antropologia Pragmática entre as ciências históricas, onde ela seria de facto uma Psicologia Empírica, ou uma mera "psicologia das observações", antes pugnando por dissociar Antropologia e Psicologia Empírica ${ }^{26}$.

Numa palavra, pois, assim dissociaria Kant a Antropologia, na sua vertente pragmática, dos restantes saberes a si tradicionalmente associados - e que, na verdade, muito tolhiam a sua autonomização. Mas, note-se, ao fazer isto, Kant não isola a Antropologia; antes reconfigura as fronteiras da Antropologia de tal modo que ela ganha uma mais coerente e mais fértil relação com vários saberes. Isto, aliás, fá-lo Kant não só ao nível da "escada" do saber racional, mediante várias ciências metafísicas - a Cosmologia Racional, a Psicologia Racional, a Física Racional - com as quais Kant admite estar a Antropologia em importante e válida relação, mas também ao nível do "solo plano" do empírico, mediante a própria Psicologia Empírica, que, enquanto uma pequena Antropologia, liga a maior Antropologia às ciências empíricas, das quais também esta depende. Ora, uma tal posição, dir-se-ia, de influência tentacular, que é aqui sugerida mediante a sua reciprocidade viva, só poderia ser obtida através da anterior dupla dissociação, e ampla reconexão da Antropologia enquanto membro-volante do esquema dos conhecimentos humanos. A sua legitimação ocorre, pois, mediante esta sua hibridização, e a sua hibridização mediante o seu carácter intermédio, ou mediador, já atrás aludido; numa palavra, mediante a posição intersticial que a Antropologia Pragmática tem de ocupar entre as diferentes dimensões do conhecimento humano. Daí que, reiteramos, a Antropologia Pragmática deva ser vista justamente como toda uma terceira dimensão do conhecimento humano; uma dimensão que, partindo do Homem - o vértice no esquema perpendicular dos conhecimentos - e abrindo cada vez mais sobre esse vértice, se estende e preenche toda a lacuna de um conhecimento cosmológico do Homem no Mundo, trazendo o individualismo da racionalidade e a multitude do empírico ao pluralismo cosmopolita ${ }^{27}$ que é próprio do pragmatismo kantiano.

26 "Dela [da Psicologia Empírica] se pode ainda distinguir a Antropologia, se por isto se entender um conhecimento do Homem na medida em que este é pragmático" (AA 29.1: 757).

27 "O oposto do egoísmo só pode ser o pluralismo, isto é, o modo de pensar em que não se atende a si próprio como o mundo inteiro, antes [um homem] se contempla e se comporta 
A presente tradução, tal como outras nossas do mesmo autor, pauta-se por um respeito e uma atenção ao cariz oral e inconstrito das lições, e à reprodução tão fiel quanto possível do mesmo, a despeito de qualquer desconforto ou estranheza que isso possa causar no leitor. Em consonância com isto, optámos por manter aqui intocadas várias características do texto transcrito na Edição da Academia - numerais, latinismos, estrangeirismos em geral, maiúsculas, etc. -, assim como respeitar, tanto quanto possível, a disposição gráfica do texto original. O mesmo optámos com respeito aos textos externos, não constantes na AA. Onde, em casos extremos, não nos foi possível atender a este método de traduzir rente ao texto - por exemplo, termos de complexa tradução, ou casos em que a inserção de palavras não constantes no original se revelou estritamente necessária -, optámos por inserir tais termos ou palavras adicionais entre parênteses rectos.

Entre parênteses rectos figuram, ao longo do texto, as referências à paginação original dos textos; aplica-se isto apenas aos casos de textos constantes na Edição da Academia (exemplo: [25: 246]). 


\section{I.}

\section{ANTHROPOLOGIE-COLLINS}

$(1772 / 73)$

\section{Prolegomena}

[25:7] A ciência do Homem (Anthropologia) tem com a fisiologia do sentido externo uma semelhança, na medida em que em ambas os fundamentos do conhecimento são tomados a partir de observação e experiência. Com efeito, nada parece ser mais interessante para os homens do que esta ciência; e, porém, nenhuma é mais negligenciada do que justamente esta. A culpa residirá, por certo, na dificuldade em situar esta espécie de observações, bem como na singular ilusão de se julgar conhecer aquilo com que se está habituado a conviver. Mediante isto, importantes partes de várias ciências foram subtraídas à consideração por não terem estas sido consideradas dignas para o efeito. Uma [outra] causa poderá bem ser esta, [a saber,] que se suponha não encontrar nada de muito de agradável, ao se empreender esta árdua viagem ao inferno que é o conhecimento de si mesmo.

Mas porque [razão] nunca foi feita uma ciência coerente do Homem a partir da grande provisão de observações dos autores ingleses? Tal parece resultar disto: porque [25:8] se considerou a ciência do Homem como uma parte anexada à Metafísica, e, por conseguinte, só se lhe dirigiu tanta atenção quanto a permitida pelas partes maiores da Metafisica. Esta falha talvez tenha nascido de um erro, pois na Metafisica tem de se extrair tudo de si próprio, e por isso se viu todas as partes da Metafísica como consequências da doutrina da alma. Mas a Metafísica nada tem que ver com os conhecimentos da experiência. A Psicologia Empírica pertence à Metafísica tão pouco, quanto a Física Empírica. Se virmos o conhecimento do Homem como uma ciência específica, daí resultam várias vantagens; pois, 1.) por amor a ela, não é preciso que se aprenda toda a Metafísica. 2.) antes que uma ciência venha à ordem e regularidade de disposição, ela tem de ser exercida nas Academias; este é o único meio de trazer uma ciência a uma certa elevação; mas isto não pode ocorrer enquanto a ciência não for rigorosamente dissociada. De livros dos quais não se tenha no entendimento, por assim dizer, disciplinas, nada se retém. A disposição é por isso o mais preeminente na ciência; se se tiver a [disposição] do conhecimento natural dos homens, assim se reúne inestimáveis reflexões e observações a partir de romances e boletins diários, de todos os escritos e do convívio. Consideraremos o ânimo humano em todos os estados, no 
[estado] saudável e no enfermo, no confuso e no selvagem, a fim de firmar os primeiros princípios do gosto e $d a$ adjudicação do belo, os princípios da patologia, da sentimentalidade e das inclinações. Tentaremos apresentar as diferentes idades e cada um dos sexos no seu carácter, e extraí-los a partir das suas fontes. Por isto se deixará depreender o que nos homens é natural, e o que neles é artificial ou adquirido por habituação; isto será o mais difícil, e o nosso [25:9] principal objecto: o de distinguir o Homem, conquanto ele é natural, do homem talhado pela educação e por outras influências, [isto é], considerar o ânimo dissociado do corpo, e mediante observações tentar aferir se a influência do corpo é necessariamente exigida para o pensar. Se provas nos mostrarem o contrário, então uma mera subsumpção a partir de experiências dar-nos-á para a mão o mais seguro fundamento comprovativo da imortalidade da alma.

Aplicar devidamente o conhecimento, as ciências, isso é o conhecimento do Mundo. Este conhecimento do Mundo consiste no conhecimento do Homem, como nos podemos tornar amáveis aos olhos deste, etc. $\mathrm{O}$ conhecimento do Mundo salvaguarda, pois, que da erudição não venha a resultar pedantismo. Os conhecimentos das singularidades da Natureza contam-se também entre o conhecimento do Mundo. Por conseguinte, a Geografia Física e a Antropologia constituem o conhecimento do Mundo. O conhecimento do sujeito é o fundamento de todos os conhecimentos. Por falta do mesmo, muitas ciências práticas quedaram-se infrutíferas, por exemplo, a filosofia moral. Os escritos de Spalding referem-se de tal modo à natureza humana, que não os podemos ler senão com agrado. Mas à maioria dos filósofos morais e dos clérigos, falta-lhes este conhecimento da natureza humana. Se possuirmos tais habilidades, as quais, por assim dizer, têm uma utilidade motivante, isso é de grande valor. Pois embora o proveito disso seja de cada vez pequeno, mediante multiplicação ele torna-se grande.

Conversas sobre a natureza humana parecem ser as mais agradáveis em convívio; pois, em sociedades, a matéria tem de ser de tal modo que cada um sobre isso possa tecer o seu juízo.

O espírito da observação torna(-nos) cautos e sóbrios.

Nós não contemplaremos os homens apenas segundo as suas propriedades ocultas, o que apenas serve a especulação, mas sim principalmente segundo as suas propriedades práticas.

A transição do movimento corporal para o espiritual não se deixa explicar para além disto; daí que Bonnet e diferentes outros muito errem, quando crêem poder subsumir com segurança a alma a partir do cérebro. 
II.

ANTHROPOLOGIE-PAROW

$(1772 / 73)$

\section{Lições sobre a Antropologia}

[25:243] A Psicologia Empírica é uma espécie de doutrina da natureza. Ela trata dos fenómenos da nossa alma que constituem um objecto do nosso sentido interno, e isso justamente do mesmo modo que a doutrina empírica da natureza, ou a Física, trata os fenómenos. Por conseguinte, discerne-se desde logo quão pouco esta doutrina pode constituir uma parte da Metafísica, pois esta tem como tópico somente os conceitos puros[:] conceitos que ou são dados apenas mediante a razão, ou, pelo menos, cujo fundamento de conhecimento reside na razão. Um tal erro dá-se, porém, em parte porque os Antigos haviam reunido ainda poucas experiências da alma, em parte porque eles não sabiam que lugar dar a esta doutrina, pois eles tomavam toda a Metafísica por uma ampla psicologia, porque a alma $e ́$ um objecto do sentido interno, mas da alma nascem todos os conceitos do entendimento. Porque agora, todavia, recebemos já uma grande colecção destas fontes das acções humanas, ou dos diversos fenómenos da alma, em especial através dos escritores ingleses, podemos expor esta doutrina da mesma maneira que expomos a Física. É de admirar que os Antigos não se tenham ocupado mais do conhecimento do Homem, embora tenham entendido esta empresa como a mais útil. E, no entanto, nada é mais comum do que julgar conhecer aquilo com que se está habituado a conviver, e não tomar por digno a investigação do mesmo. Esta opinião, que nos foi incutida, causou enorme prejuízo nas ciências, e privou-nos do conhecimento de muitas coisas. Ao mesmo tempo, porém, há que notar que as ciências, justamente porque são leccionadas nas Academias em uma certa ordem, e dissociadas de outras ciências, vêm registando um grande crescimento e uma grande expansão. Justamente este é o caso da Psicologia Empírica, [25:244] pois enquanto ela foi anexada à Metafísica, e não leccionada isoladamente, ela era de um alcance muito exíguo. Ela merece também um curso particular, em parte porque ela não pertence de todo à Metafísica, em parte porque ela pode ser aprendida por todos, sem que para isso sejam exigidas ciências prévias. Aqui se pode aprender as fontes de todas as acções humanas e o carácter dos homens na sua conexão, os quais, aqui e ali, nas ciências, em romances e em alguns ensaios de moral, se encontram dispersos. Por conseguinte, qualquer traço da humanidade que se encontre num escrito pode ser extraído da fonte 
desta [da Psicologia Empírica], e assim aumentado o nosso conhecimento dos homens. Montaigne, que há 200 anos escreveu um livro em francês antigo, é até hoje merecedor do respeito de qualquer erudito racional, pois, a partir da sua obra, aprende-se a conhecer os homens nas suas diferentes circunstâncias; embora, de resto, esta obra seja algo desagradável de ler, pois Montaigne fala sempre de si mesmo.

Ao se tratar esta doutrina, queremos também contemplar os homens em diferentes estados, por exemplo, no estado selvagem e não-civilizado, de acordo com a sua diferente idade, etc., e queremos distinguir o que em um homem é natureza, e o que é $\operatorname{arte}^{28}$.

\section{III.}

\section{ANTHROPOLOGIE-FRIEDLÄNDER}

(1775/76)

\section{Prooemium}

[25:469] Toda a habilidade que se possui exige no fim um conhecimento da maneira como disso havemos de fazer uso. O conhecimento que está como fundamento à aplicação designa-se por conhecimento do Mundo. O conhecimento do Mundo é um conhecimento do palco sobre o qual podemos aplicar toda a habilidade. Os conhecimentos são de índole dupla, perfeição teorética e [perfeição] pragmática. A teorética consiste em sabermos o que é exigido para certos fins finais, e, por conseguinte, visa o entendimento; a pragmática consiste na faculdade de julgar, [na capacidade] para nos servirmos de toda a habilidade, ela é necessária como selo de toda a nossa habilidade. $\mathrm{O}$ fundamento do conhecimento pragmático é o conhecimento do Mundo, onde se pode fazer uso de todos os conhecimentos teoréticos. Por Mundo é aqui entendido o complexo de todas as relações a que o Homem pode vir, onde ele pode exercitar as suas visões [Einsichten] e habilidades. O Mundo, enquanto um objecto do sentido externo, é Natureza; o Mundo, enquanto um objecto do sentido interno, é o Homem. Assim, o Homem pode surgir em uma relação dupla: em relações em que ele tem necessidade do conhecimento da Natureza, e em relações em que ele tem necessidade do conhecimento do Homem. O estudo da Natureza e do Homem constitui o estudo ou o conhecimento do Mundo. Quem tem muitos conhecimentos teoréticos, quem sabe muito, mas não tem nenhuma habilidade para disso fazer uso, esse é erudito para a

${ }^{28}$ Artificial, artificialidade [n.d.t.]. 
Escola, mas não para o Mundo. E esta habilidade é o pedantismo. Pode-se ter habilidade para algumas relações, por exemplo, ser bem apto para a Escola; mas, não obstante, falta-nos uma habilidade geral em todas as relações em que incorremos. Ora, porque o Homem não sabe a que espécie de relações pode vir, então é necessário adquirir conhecimentos indeterminadamente, em todas as relações. O conhecimento de todas [25:470] as relações é o conhecimento do Mundo. Para se ter conhecimento do Mundo há que estudar um todo, todo a partir do qual se pode posteriormente determinar as partes: e isso é um sistema, desde que o múltiplo tenha nascido a partir da ideia de todo, e tem um sistema aquele que sabe dar ao múltiplo um lugar no todo dos conhecimentos, o qual se diferencia do agregado, onde um todo nasce não mediante a ideia, mas mediante composição. Ora, se eu estudo as relações das coisas, e se estou em condições de indicar às partes múltiplas um lugar no todo, então eu tenho um conhecimento da Natureza. Mas eu posso indicar às coisas um lugar nos conceitos, então isto seria um sistema da Natureza, ou eu posso indicar às coisas um lugar em locais, e isto ocorre na Geografia Física.

A Geografia Física pertence ao conhecimento do Mundo como sua primeira parte, na medida em que é pragmática. Aqui desaparecem muitas observações físicas, só é tomado o que é necessário com respeito ao conhecimento do Mundo, isto é, [o que] é exclusivamente pragmático. A segunda parte do conhecimento do Mundo é o conhecimento do Homem, que é considerado na medida em que o seu conhecimento nos interessa na vida. Assim, aplicando o seu conhecimento não especulativamente, mas pragmaticamente, segundo regras de prudência, é o Homem estudado, e isso é a Antropologia. Nada nos interessa tanto quanto um outro homem, não é a Natureza o objecto do nosso afecto, mas sim o Homem. Nós não atendemos tanto a nada, quanto àquilo que nos pode dizer respeito em vista de outros homens. A Natureza não nos pode conceder senão comodidade e entretenimento, o que apenas pode vir a ter lugar entre homens, e todas as circunstâncias de miséria com respeito à comodidade e ao entretenimento, só não as podemos tolerar na medida em que nós não as possamos ter em comum com outros homens. Até mesmo com respeito às nossas circunstâncias indigentes, nós deploramos não a Natureza ela mesma, mas que outros homens tenham [algo] melhor do que nós. Se a minha refeição for sempre água e pão, isso atormenta-me porque eu sei que outros homens têm melhor; mas se a cidade for sitiada, e todos juntos na cidade comerem o mesmo, então eu vejo-me saciado e de coração alegre perante o meu fraco alimento, pois nisto nenhum [homem] tem sobre mim privilégio. Por isso, interessa-nos mais o Homem do que a Natureza; pois a Natureza é 
devido ao Homem, o Homem é o fim da Natureza.

[25:471] Diz-se: o Homem conhece o mundo quando ele é viajado, e o viu. Mas aí não existe ainda nenhum conhecimento do Mundo, pois conhece o mundo quem conhece os homens. O conhecimento dos homens, por sua vez, pode ser duplo.

1. O comportamento ou conduta fortuitos dos homens, ou a [sua] situação

2. A natureza da humanidade

Mas a Antropologia não é uma [antropologia] local, antes uma antropologia geral. Aí se aprende a conhecer não a situação dos homens, mas sim a natureza da humanidade, pois as propriedades locais dos homens estão em constante alteração, mas não a natureza da humanidade. A Antropologia é, por isso, um conhecimento pragmático daquilo que flui a partir da natureza do Homem, mas não um [conhecimento] físico ou geográfico, pois estes estão anexados a tempo e lugar, e não são constantes. Quem é viajado e conheceu muitos homens, quem conheceu a situação e as modas das mais afamadas cidades, desse não se pode porém dizer que conheça os homens, pois ele conheceu apenas a situação [destes], que é deveras mutável[.] Mas se eu conheço a humanidade, isso tem de se adequar a todas as espécies de homens. Por conseguinte, a Antropologia não é uma descrição dos homens, mas sim [uma descrição] da natureza dos homens. Assim, consideramos o conhecimento do Homem com respeito à sua natureza. O conhecimento da humanidade é, a um tempo, conhecimento de mim mesmo. Como fundamento tem de residir, pois, um conhecimento natural segundo o qual se possa ajuizar o que reside como fundamento em cada homem; assim, temos princípios seguros segundo os quais podemos proceder. Por esta razão temos de nos estudar a nós mesmos, e porque queremos aplicar isto a outros, então temos de estudar a humanidade, mas não psicologicamente ou especulativamente, mas sim pragmaticamente, pois todas as doutrinas pragmáticas são doutrinas da prudência, onde, para todas as nossas habilidades, temos também o meio para fazer de todas um uso apropriado; pois nós estudamos os homens para nos tornarmos mais prudentes, prudência essa que se torna ciência. Por conseguinte, não devemos viajar para estudar os homens, antes podemos contemplar a natureza destes por todo o lado. Mas o Homem, o sujeito, tem de ser estudado se é que ele há-de prestar aquilo que se exige que ele faça[.] Que a Moral e os sermões, os quais estão repletos de admoestações das quais nunca nos cansamos, tenham menos [25:472] efeito, disso é causa a falta de conhecimento do Homem. A Moral tem de estar aliada ao conhecimento da humanidade. 
A aquisição de muitos vícios não é consequência da Moral e da Religião, mas sim do refinamento. Omite-se os vícios não porque eles sejam contrários à Moral, mas porque eles são tão grosseiros. Mas, para que a Moral e a Religião alcancem o seu fim último [Endzweck], a estas tem de estar associado o conhecimento dos homens. A Natureza tem os seus fenómenos, mas o Homem tem também os seus fenómenos. Até hoje, ninguém escreveu ainda uma história do Mundo que fosse ao mesmo tempo uma história da humanidade, antes apenas [se escreveu sobre] a situação e a transformação dos reinos: o que, enquanto parte, é por certo algo grandioso, mas que, uma vez tomado no todo, é uma minudência. Toda a história de guerras resulta em uma e a mesma coisa, na medida em que não contém senão descrições de batalhas. Ora, se uma batalha foi mais ou menos [bem] vencida, isso nada importa no todo. Assim, dever-se-ia atender mais à Humanidade. Hume, com a sua História da Inglaterra, deu disto uma prova. Observar os homens e a sua conduta, trazer os fenómenos destes sob regras, é o fim da Antropologia. De todas as antropologias até hoje existentes, nenhuma teve ainda a ideia que aqui temos perante nós. Tudo o que não tem nenhuma relação com a conduta prudente dos homens não pertence à Antropologia. Só pertence à Antropologia aquilo de que, no mesmo momento, se pode extrair um uso prudente na vida. Onde as ideias nascem, isso pertence à especulação, e não à Antropologia, como o fez Platner.

Mediante o que nasce a Antropologia? Mediante a colecção de muitas observações de homens por parte de autores que tinham do Homem um sagaz conhecimento. Por exemplo, as peças dramáticas de Shakespeare, o Spectator inglês e os Ensaios de Montaigne, a par da vida deste, que é também um livro para a vida, e não para a Escola. O campo [25:473] do humano é muito amplo, e por isso ele merece ser exposto como um todo, e não anexado a outras ciências; pois a Física é o conhecimento do objecto do sentido externo, e o conhecimento do Homem enquanto o objecto do sentido interno constitui justamente um tal campo, e portanto ele merece um tal esforço, e, enquanto tal, ser versado como uma ciência em Academias, como o é a Física. E, no fundo, o Homem é mais merecedor de ser estudado, e mais digno que se [lhe dedique] tais considerações, do que toda a Natureza corpórea. Pensou-se que em uma ciência haveria sobre isto muito pouco a dizer, e por essa razão se inscreveu [a Antropologia] na Metafísica, e logo na Psicologia, que aí constitui a Psicologia Empírica[;] esta, porém, de modo algum aí pertence, na medida em que a Metafísica nada tem que ver com nenhuma ciência empírica. 


\section{IV. \\ ANTHROPOLOGIE-PILLAU \\ (1777/78)}

\section{Antropologia. Prolegomena}

[25:733] Não existe para os homens nenhuma investigação maior e mais importante do que o conhecimento do ser humano. Este, porém, foi por muitos tomado como muito fácil, e isso devido às seguintes causas:

1) Julgou-se que disto não era necessária nenhuma disciplina, pois esta, poder-se-ia aprendê-la facilmente mediante o convívio; e, por isso, ela foi tomada como muito fácil, embora não como indispensável. O mesmo acontece com a Moral: cria-se que a mesma era importante; mas fazer disto uma ciência seria supérfluo.

2) Tomou-se [a Antropologia] como não sendo sobremaneira importante. Os homens, porém, são em grande parte o maior objecto da nossa consideração[;] e, porém, todas as paixões concernem apenas aos homens. Por outro lado, tomou-se [a Antropologia] como não sendo tão necessária, pois, segundo parecia, a conduta dos homens não teria nenhumas leis. Contudo, esta observação dos homens é uma das mais agradáveis matérias.

Podemos considerar este conhecimento do Homem de um modo duplo.

1) Como um [conhecimento] especulativo. Pois só na investigação do desejo de conhecer se pode satisfazer o entendimento;

2) Como um [conhecimento] pragmático que não visa nenhum outro conhecimento, a não ser aquele conquanto dele se extraia uma utilidade comprovada.

Como Mundo, tomamos:

1) A Natureza; 2) Os Homens. Por conseguinte, estes são postos em oposição; pois o Homem é o único ser que age livremente no solo terrestre, mas natureza e liberdade são opostas. Na Geografia Física consideramos a Natureza, ao passo que na Antropologia [consideramos] o Homem, ou a natureza humana em todas as suas situações. Ambas estas ciências constituem o conhecimento do Mundo. 
Quanto mais se começa a considerar a natureza de uma coisa, tanto mais se começa a amar a coisa ela mesma. Por conseguinte, [25:734] se se considera a natureza humana, então sempre nos é incutido um amor maior em relação à mesma.

\section{Diferença do conhecimento do Mundo}

1) Um conhecimento do Mundo local, como o que têm os comerciantes, é também designado por empírico. 2) um conhecimento do Mundo geral, como o que tem o Homem do Mundo, é não empírico, mas sim cosmológico. $\mathrm{O}$ [conhecimento] local está associado a lugar e tempo, e tão-pouco dá para a mão regras [sobre como] agir na vida comum. Aquele que conheceu o Mundo através de viagens, esse tem dele apenas esse conhecimento, o qual, porém, apenas dura algum tempo, pois se os comportamentos no local onde ele esteve se alteram, então logo cessam também os seus conhecimentos disto.

Assim, onde havemos de conhecer melhor o Mundo, sem por ele viajar?

1) A consideração dos homens à nossa volta e uma forte reflexão podem substituir a extensa experiência, e ultrapassam em muito aquela que é recebida por um viajante que não pensa. Os homens mostram as fontes das suas acções tanto em um pequeno espaço como no grande Mundo, algo para o que apenas é exigido um olhar atento, e só provido destes conceitos um viajante pode empreender a viagem, se quiser viajar com proveito.

2) O convívio civil. O essencial aqui é a atenção às convicções humanas, as quais, amiúde, se mostram sob muitas formas.

3) As peças, romances, histórias e em especial as biografias.

\section{Utilidade da Antropologia}

1) Quanto melhor conhecemos os homens, tanto melhor sabemos orientar as nossas acções de tal modo que estas coincidam com as destes.

2) Ela ensina como se conquista homens.

3) Ela ensina a auto-satisfação, quando se encontra em si mesmo o bem que se encontra em outros.

4) Ela dá-nos para a mão os princípios subjectivos de todas as ciências. [25:735] E estes princípios subjectivos têm uma grande influência

1) Na Moral,

2) Na Religião,

3) Na Educação. 


\section{V. \\ ANTHROPOLOGIE-MENSCHENKUNDE (1781/82)}

[25:853] Há que distinguir duas espécies de estudo: há ciências cismantes que em nada beneficiam o Homem, e houve outrora filósofos cuja ciência consistia toda ela em se suplantarem estes uns aos outros em sagacidade, estes eram designados por scholastici; a sua arte era ciência para a Escola, mas a partir desta não se podia ganhar nenhum esclarecimento para a vida comum. Um [indivíduo] pode ser um grande homem, mas apenas para a Escola e sem que o Mundo tenha proveito do seu conhecimento. Uma segunda espécie de estudo consiste em que não se granjeie respeito apenas junto dos colegas da Escola, mas que o saber se estenda para além da Escola, e se procure ampliar o conhecimento para um proveito geral: este é o estudo para o Mundo. Escolar é uma ciência que é conforme à Escola e às normas da profissão; esta é uma perfeição não despicienda, pois, antes de mais, todas as ciências têm de ser escolares; depois elas podem também ser populares, a fim de serem tomadas e utilizadas por meros amadores. Em primeiro lugar, a ciência deve satisfazer os estudantes por ofício, e depois há que ver como ela pode ser mais bem apreendida por homens comuns. Aquele que faz dos seus conhecimentos um uso escolástico é um pedante, ele só sabe designar os seus conceitos com as expressões técnicas da Escola, e fala apenas em dialectos eruditos; ele faz um uso de conceitos meramente escolásticos no Mundo; mas aqui, há que entender como aplicar conhecimentos apenas de modo popular, para que também outros, não apenas eruditos de profissão, nos entendam. É motivo de riso, quando pedantes utilizam os seus conhecimentos de tal modo inabilmente, que fazem dos mesmos um uso escolástico no Mundo; pois nada é mais risível do que quando um [indivíduo] não mostra nenhum poder de discriminação [judicium discretivum], e não vê o que se presta às circunstâncias. Por isso é que o pedante, que de resto pode ser um homem cheio de méritos, dá amiúde ocasião para riso. Por conseguinte, é necessário que aprendamos a fazer um uso popular dos conhecimentos adquiridos nas universidades, para que no convívio com homens saibamos como queremos formar homens, ou tornar-nos amáveis junto destes. Devemos [25:854] ter que ver não com a Escola, mas com o Mundo, e por isso temos de estudar o Mundo. Um homem tem mundo, amiúde, quando sabe pouco, mas logra comunicar bem esse pouco a outros homens. Alguém pode ser muito erudito, mas se não tiver conhecimento do Mundo, ele não pode fazer disso 
nenhum uso benéfico, e assim promover o seu proveito e o da república. De resto, conhecimento do Mundo designa-se também por conhecimento da Natureza, mas tal não é o significado da linguagem popular: aí, ela designa-se apenas por conhecimento do Homem.

O Homem conhece o mundo, isto é, ele conhece os homens em todas as situações. Conhecimento do Mundo, em sentido comum, é designado por conhecimento dos Homens. Os franceses dizem que o Homem tem Mundo, isto é, ele tem conhecimentos que não consistem simplesmente em especulações, mas que ele sabe trazer ao homem [comum]. Nós carecemos do auxílio de outros homens para alcançar outras coisas; daí que, preferencialmente, se chame ao conhecimento do Mundo conhecimento do Homem. O que há então a fazer para se conhecer o Mundo? Para aceder ao conhecimento deste, um embarca em viagens, o outro sai do seu círculo familiar e expande o seu convívio até à parte da sociedade humana, que é a mais [bem] formada, isto é, até à parte preeminente. No início, o seu convívio estava restringido apenas à sua família, aos seus companheiros na escola, depois ele transita para pessoas mais refinadas. O exercício e a experiência facultam-nos a melhor escola para aprender a conhecer os homens, mas por si só não chegam para consumar o nosso conhecimento do Mundo e para [o] tornar prático. Sem que se aprenda a reflectir sobre os homens, não se será muito instruído mediante o convívio. Por conseguinte, há que antecipadamente trazer o outro àquilo em que ele tem de atentar no Homem; há que apresentar disto ideias fundamentais, segundo as quais se possa adquirir conhecimento do Homem[.] Se não se for instruído, pode-se conviver longamente com homens sem se aperceber de algo nestes. Mas se nos tiverem mostrado os momentos principais em que temos de atentar, sabemos o que temos de notar. Por isso, ao conhecimento do Homem pertence uma instrução completa do múltiplo e do característico no Homem. Os dois últimos são de grande importância e sempre têm de preceder o conhecimento do Homem, [25:855] e mediante isto as experiências têm de ser ampliadas. Munido destas instruções, pode-se aprender mais em pouco tempo do que outros em toda a sua vida; pois uma vez elas estejam como fundamento, torna-se fácil ampliá-las, e mediante isto tem-se também mais prazer no convívio, pois a maior parte do mesmo consiste principalmente em reflexão. Amiúde, um tom malicioso pode causar um tédio mortal; mas uma cabeça pensante sempre encontra em tais insocialidades matéria para as suas considerações; por ocasião destas ele aprende, e não consumiu o seu tempo de modo desagradável. Estes conhecimentos preliminares hão-de ser os necessários para que se progrida no conhecimento do Homem. 
Há três espécies de doutrinas, todas elas contribuindo para a nossa perfeição. Uma espécie torna-nos hábeis, a outra prudentes, a outra sábios. Para a habilidade servem todas as ciências da Escola; assim se aprende História, por exemplo, para se ser hábil com respeito a coisas da experiência. Se quisermos dar um passo no Mundo, temos de aprender como havemos de nos tornar prudentes.

O grau mais elevado de sabedoria é a maior perfeição, mas esta só raramente é alcançada. O hábil é o teorético, a Escola, mas a indicação que nos torna prudentes é a indicação para o prático, como havemos de fazer uso da nossa habilidade. A habilidade é dirigida a coisas, a prudência a homens. O relojoeiro é hábil se fizer um relógio perfeito; mas se ele souber trazê-lo rapidamente ao homem, por o saber fazer bom segundo a moda, então ele é prudente. Só quando lograrmos granjear uma influência sobre homens, teremos também uma influência sobre coisas; pois mãos humanas tudo produzem a partir da natureza bruta. A prudência repousa, pois, apenas sobre o conhecimento do Homem, por força do qual estamos em condição de orientar outros segundo o nosso propósito.

O conhecimento do Homem é de índole dupla: o conhecimento especulativo do Homem torna-nos hábeis e é tratado na Psicologia e na Fisiologia, mas o prático torna-nos prudentes; ele é um conhecimento [versando] a maneira como um homem pode ter influência sobre o outro e o pode orientar segundo o seu propósito. Todo o conhecimento prático, assim ele sirva para cumprir todos os nossos propósitos, designa-se por pragmático. Toda a doutrina da sabedoria [25:856] é moral, e toda a [doutrina] da prudência é pragmática. Uma doutrina é pragmática desde que nos torne prudentes e úteis em questões públicas, onde precisamos não apenas de teoria, mas também de prática.

O conhecimento do Homem, designamo-lo por um nome geral, Antropologia, a qual não é leccionada em nenhuma outra academia. Platner escreveu uma antropologia escolástica. Nós, porém, não temos como propósito senão extrair regras a partir do múltiplo que percebemos nos homens; pois, por muito incrivelmente diferentes que os humores humanos possam parecer ser, há aqui porém mais conformidade a regras do que se possa pensar. Este jogo das acções humanas, tentaremos trazê-lo sob regras. Todo o homem se alegra em vista de uma regra; por exemplo, Sharp, um médico inglês, diz a dada altura que na Inglaterra todos os homens são grosseiros, à excepção dos estalajadeiros, ao passo que na França todos os homens são refinados, à excepção dos estalajadeiros. A causa é: na Inglaterra há muitos estalajadeiros, na França poucos. Esta regra apraz, ainda que ela não possa ter um fundamento constante. 
Das regras na nossa antropologia, não daremos nenhumas causas senão aquelas que podem ser observadas por todos, sem que se complemente com a teoria das mesmas. Procuraremos as regras nas experiências múltiplas que notamos nos homens, sem perguntar pela causa das mesmas. A antropologia escolástica trata das regras mais gerais e suas causas; assim, logo que investiguemos sobre a causa das regras, entramos no escolástico. A nossa antropologia [25:857] pode ser lida por todos, até por senhoras na toilette, pois ela muito entretém, na medida em que por todo o lado se pode encontrar regras que dão informação, e na medida em que mesmo entre a aparente desordem se encontra um fio condutor.

Quais são, pois, as fontes da Antropologia? Se as molas propulsoras dos homens estão em actividade, ele não observa as mesmas; por exemplo, quando ele está em afecto, ele não logra observar-se no jogo das suas molas propulsoras. Mas quando ele se observa, todas as molas propulsoras repousam, e, portanto, ele nada tem para observar. É por isso difícil observar o ânimo do Homem assim que as suas molas propulsoras estão em jogo. Contudo, esta dificuldade é minorada conquanto se comece a observar outros, pois aí pode-se estar deveras silencioso e, de tempo a tempo, estas observações podem ser aplicadas a si mesmo; pois, porque se está já em posse de certos conhecimentos, então, quando o nosso ânimo está em actividade, é possível que em vista disto nos observemos mais correctamente. O convívio com muitas situações e com homens cultivados é uma fonte muito fértil de Antropologia. Em homens rudes a humanidade não se desenvolveu ainda completamente, pois eles não têm ocasião para desenvolver todas as propriedades da mesma. Mas se eu me dirigir à parte civilizada dos homens, deparo-me com a dificuldade segundo a qual, quanto mais cultivado é o homem, tanto mais ele se dissimula e tanto menos ele quer ser pesquisado por outros. O cortesão não quer ser estudado, e esta arte para encobrir aumenta com o crescimento da formação, onde [um indivíduo] não só se dissimula, antes mostra em si também o contrário disso. Por conseguinte, temos de observar os homens de tal forma que de modo algum ostentemos a aparência de um observador, e, por isso, também nós temos de nos dissimular. Há que se dispor como se se falasse sem circunspecção, e, porém, tomar atenção a tudo o que os outros dizem. Ainda assim, é sempre difícil conhecer homens enquanto se observa as acções destes, pois isto exige um observador formado e perspicaz.

Uma outra fonte da Antropologia é a História; mas antes, tem de preceder uma Antropologia; pois se eu não sei a que tenho de prestar atenção, então, mediante a narração apenas, não saberei em que tenho de atentar. Podem romances, [25:858] comédias, peças, tragédias, por exemplo, as 
de Shakespeare, providenciar conhecimentos antropológicos? As peças e os romances exageram sempre aquilo que, de outro modo, seria uma mera propriedade de um homem. Os autores baseiam-se de facto em observações correctas, mas veiculam caricaturas, isto é, carácteres exagerados. Ao invés, a Antropologia aprecia as peças e os romances [aferindo] se eles concordam com a natureza humana. Com efeito, há homens, embora apenas poucos, que sabem apresentar os seus conhecimentos do Homem de modo igualmente adequado em comédias e tragédias. Toda a Moral exige conhecimento dos homens, para que não lhes papagueemos advertências ocas, antes saibamos orientá-los de tal modo que comecem a ter em grande estima leis morais, e a ater-se aos princípios destas. Eu tenho de saber que acessos posso ter às convicções humanas, a fim de produzir deliberações; para isso pode dar-nos ocasião o conhecimento do Homem, de tal modo que o educador, o pregador estejam em condições de produzir não apenas soluços e lágrimas, mas sim verdadeiras deliberações. Na política, ela é igualmente indispensável; pois para se poder governar homens, tem de se conhecer homens; sem conhecimento do Homem, o governante não pode orientar um tal conjunto de situações, tudo se lhe opõe e ele não pode conduzi-las segundo a sua vontade.

Um grande benefício da Antropologia consiste no convívio, de tal modo que ela nos torna hábeis para o mesmo, e nos oferece também uma muito bela matéria para entretenimento; pois muitas matérias não são para a sociedade; a mulher não pergunta por questões de Estado, antes quer ser entretida, e aí se descobre que certas observações sobre os homens agradam porque qualquer um pode proferir as mesmas sobre si. Assim, porque este estudo é tão cativante e tão importante para qualquer um, então ele tem de ser estimado por direito próprio. Muitos escritores afirmam que é difícil conhecer-se a si mesmo. Se eu tiver de me conhecer por comparação com outros, e a pergunta for se eu me conheço melhor do que a outros, então é evidente que todo o homem tem de poder-se conhecer-se melhor a si mesmo; pois se ele pode procurar o fundamento de todos os seus pensamentos e molas propulsoras, e se com respeito a si mesmo, ou ao seu próprio conhecimento, não pode existir nenhuma dissimulação ou encobrimento, então eu não sei [25:859] quem posso conhecer melhor do que a mim mesmo. Mas se se disser: conhece o Homem em geral, então o conhecimento do Homem é com efeito difícil, pois se eu quiser conhecer o Homem, não o posso comparar com nenhum outro; se eu quiser conhecer-me a mim mesmo, segundo aquilo que tenho de diferente em relação a outros, então eu posso comparar-me com outros, e portanto conhecer-me mais rigorosamente. Mas se eu pergunto: o que é o Homem?, 
eu não posso compará-lo com os animais, pois é para ele um privilégio não ser um animal, e de outros seres racionais não temos conhecimento. Por isso, o conhecimento do Homem em geral é difícil, o conhecimento específico de um homem é já mais fácil, e o mais fácil é o auto-conhecimento; pois de mim não me posso eu encobrir, e, por conseguinte, aqui desaparecem todas as cobertas colgadas por outros homens.

Porque não há nenhum outro livro sobre Antropologia, tomaremos como fio condutor a psicologia metafísica de Baumgarten, um homem que é muito rico na matéria, e muito conciso na exposição.

\section{VI.}

\section{ANTHROPOLOGIE-MRONGOVIUS}

\section{$(\mathbf{1 7 8 4 / 8 5 )}$}

\section{Primeiro capítulo \\ Introdução à Antropologia}

[25:1209] Há dois modos de estudar, na Escola e no Mundo. Na Escola, aprende-se conhecimentos escolásticos que se prestam a eruditos por profissão; no convívio com o Mundo, porém, conhecimentos populares que se prestam a todo o Mundo.

Quem quer usar no Mundo os conhecimentos escolásticos que só são usados na Escola e em escritos eruditos, sem ver se eles interessam ou não, é um pedante; na matéria, por certo, ele tem realmente muito conhecimento, apenas não sabe expor compreensivelmente o seu saber, só em forma escolar, e portanto ele é um pedante na maneira[.]

A palavra pedante vem originariamente do Latim, pois na Itália chamava-se aos tutores domésticos magistri pedanei. A partir disto, a palavra pedanto, na medida em que se deixou cair magistério e se transformou pedanei em pedanto, veio a ser a palavra alemã pedante [Pedant]. Supostamente, estas pessoas não se deixavam ausentar dos seus quartos de estudo, em convívio usavam apenas os seus conhecimentos escolares e, por conseguinte, davam azo a que se chamasse um pedante a todo aquele que não se soubesse adaptar ao convívio com homens. Um pedante pode fazer dos seus conhecimentos um uso exclusivamente escolástico, pois ele não sabe aplicá-los melhor e não conhece [para estes] nenhum outro uso.

Escola é a aquisição do conhecimento que se tem de aplicar no Mundo, pois a Escola mostra-nos a habilidade para adquirir conhecimentos, mas não [como fazer] dos mesmos uso para o Mundo. 
Escolar é um conhecimento se ele for adequado ao método da Escola, isto é, se profundidade, completude, adequabilidade e clareza forem a essência de um conhecimento[.] Para [25:1210] se fazer da sua habilidade uso para o Mundo, para isso é ainda necessário um conhecimento que, as mais das vezes, se aprende a usar mediante o convívio e mediante experiência. Este conhecimento designa-se por conhecimento do Mundo, não o conhecimento de toda a Natureza, mas sim do Homem. Pois aos homens se referem todas as ciências, e se se tomar em conjunto todos os nossos fins, eles desembocam porém no Homem.

Obtém-se conhecimento do Mundo, ou conhecimento do Homem, mais de experiências do que de prescrições; ainda assim, existem algumas destas.

A habilidade é muito diferente de prudência, pois a habilidade é uma destreza no uso de meios na Natureza. A prudência, porém, é uma destreza ou conhecimento para alcançar os seus propósitos, para fazer uso desta habilidade ou para usar outros homens para os seus propósitos; para isso, porém, tenho de me servir daquilo que é para todos compreensível, e que a todos interessa. Por conseguinte, toda a instrução pragmática torna[-nos] prudente[s]. Assim, o conhecimento do Mundo não visa o conhecimento da Natureza e a habilidade, mas sim, em genuíno sentido, a prudência[.]

Pode-se aceder à prudência de diferentes modos; ou

1.) mediante experiência própria[:] mas esta é em parte demasiado tardia, em parte tem de ser aprendida mediante danos próprios; ou

2.) mediante observações de outros [-] isto é o mais aconselhável; ou

3.) mediante aprendizagem de certas prescrições que nos podem servir como exercícios preparatórios, e que são a experiência de outros homens

Conhecimentos do entendimento são práticos se deles se puder em geral fazer uso; mas pragmáticos, se se puder fazer deles uso geral na sociedade, e aqui eles têm de ser 1 . universalmente compreensíveis e 2. também interessantes para todos. A prática torna-nos hábeis para todos os fins sensíveis, quer estes nos interessem, quer não - mas, [para cada um,] a prudência é um fim real a ser determinado[.]

O conhecimento do Homem em geral dá por um outro nome, Antropologia. Esta, por sua vez, é também dupla: ou 
1 Anthropologia pragmatica, se ela considerar o conhecimento do Homem como ele é geralmente empregável na sociedade, ou

2. Anthropologia scholastica, se ela for considerada (tratada) mais como um conhecimento de Escola. A primeira é a aplicação da última em uma sociedade. Uma antropologia da última [25:1211] espécie, editou-a recentemente Platner: [uma antropologia] que descreve a constituição do corpo e da alma, por exemplo, as causas da imaginação, dos sonhos e por aí diante. Mas com esta não temos nós nada que ver, antes queremos tratar a Antropologia pragmaticamente, ou como um conhecimento do Mundo, e deste modo nunca foi ela até hoje tratada. Na antropologia escolástica eu investigo as causas da natureza humana. Na pragmática, eu atendo apenas à constituição [Beschaffenheit], e procuro aplicá-la. A Antropologia é designada por pragmática se servir não para erudição, mas para prudência.

Se se usar a Antropologia para o convívio, isso é conhecimento do Mundo. Podemos empregá-la diariamente em conversas, ofícios e com respeito a nós mesmos, e ilustrá-la sempre mais mediante novas observações. Em tal respeito - a saber, como conhecimento do Mundo -, a Antropologia não foi ainda tratada por ninguém, e foi o Professor Kant o primeiro a fazer o plano para a mesma e a expô-la nos seus collegien.

A utilidade da Antropologia é múltipla

I. Com respeito às ciências

a Com respeito à Moral e à Teologia homilética

Aqui, há que fazer preceder o seguinte. Existem três espécies de doutrinas

1. A doutrina da habilidade, que comunicamos já às crianças e mediante a qual aprendemos as coisas como elas são

2. a doutrina da prudência, que se aprende apenas com o incremento de faculdade de julgar, e que ensina a aplicar a habilidade

3 a doutrina da moralidade, que visa todos os fins do Homem e mediante a qual se vem a ser sábio. A habilidade é escolástica, a prudência pragmática e a sabedoria moral.

A Antropologia é pragmática, mas serve para o conhecimento moral do Homem, pois a partir dela se tem de criar as motivações para a Moral, e sem ela a Moral seria escolástica e de modo algum aplicável no Mundo, e para 
os homens desagradável. Antropologia relaciona-se: Moral = Geometria espacial: Geodesia

[25:1212] Desta maneira, a Antropologia cria grande benefício para a Teologia homilética, ou instrutiva.

b. Com respeito à História.

A História é dupla

1.) escolástica, quando eu sei apenas o que aconteceu, e

2.) pragmática, quando eu investigo os propósitos privados dos homens e os propósitos públicos da república.

Com efeito, a história pragmática cria um proveito; pois se eu só sei a História escolasticamente, ele vale-me de tanto como um conto ou um romance.

A Antropologia é incontornavelmente necessária para a história pragmática. Pois onde queremos [encontrar] ressonância de uma história, se não conhecemos os homens e não podemos explicar as causas das ocorrências a partir das inclinações e paixões destes? Aliás, sem uma Antropologia, nem sequer o projecto para uma história pragmática podemos fazer.

Exige-se agora de uma história que seja pragmática, mas há muito poucos livros de história que sejam escritos de modo verdadeiramente pragmático. Pois, porque os autores possuem muitos livros de história, mas pouco conhecimento do Homem, eles não logram fazer um conceito correcto de uma história pragmática, quanto mais pô-lo em execução.

Mas a Antropologia é, também ela, ampliada pela História, e [por esta] dilucidada com novas observações. Pois da História eu posso tirar exemplos, e assim, ambas as ciências estão alternadamente aliadas uma à outra

2. Com respeito ao convívio

1 A Antropologia forma o Homem para o convívio, e é um exercício preparatório para o conhecimento amplo do Homem, que se alcança mediante viagens. Com efeito, muitos que entram em boas sociedades formam pouco a pouco o seu inicialmente [25: 1213] grosseiro trato. Mas muitos não têm ocasião de o fazer, e então, um conhecimento do Homem que eu alcanço mediante convívio é meramente efémero e consiste apenas em cumprimentos da moda e modos de falar. Ele não tem nenhum verdadeiro conteúdo, e não interessa a todos; daí que as pessoas mais entusiásticas sejam, amiúde, as cabeças mais vazias[.]

2.) Mas um sólido conhecimento do Homem interessa a todos, e dá matéria para entretenimento, até mesmo para senhoras, como o diz Cremes, em Terêncio: "eu sou um homem, o que diz respeito aos homens 
concerne-me também a mim"[;] pois, aqui, todo o homem se em condição de investigar isto[.] Por conseguinte, tudo o que é abstracto, a saber, tudo o que tem de ser investigado com grande esforço, não tem aqui o seu lugar, e, porém, tão-pouco deve ser completamente vulgar.

3.) Ela ensina-nos também a conhecermo-nos correctamente. $\mathrm{O}$ conhecimento do Homem, ou Antropologia, é necessário a todos os homens. Pois, mediante ela, pode ele fazer devido uso da sua habilidade, e também instaurar muito benefício, mas também precaver-se de muitos incómodos.

\section{As fontes da Antropologia são auto-observação, História, em parte também romances e peças}

Da auto-observação e da História, falámos já acima. Romances e peças servem também para a Antropologia, e dão amiúde azo a correctas observações, mas delas, só pode beneficiar aquele que tiver já algum conhecimento do Homem, e apenas um tal homem as pode fazer; aliás, o conhecimento humano que este contém é a única coisa atraente nele. Daí que, por exemplo, as peças de Shakespeare sejam obras-primas, pois ele tinha do Homem um profundo conhecimento. Mas ambos têm a falha de iludir. Pois os romances tornam as paixões cálidas, e representam a humanidade em traços exagerados. As peças, aliás, têm de usar traços exagerados, e quando se diz que um retrato caricatura é estúpido porque ocorrências passadas durante anos são aí representadas em algumas horas, há que tentar tornar invisível este erro, que de outro modo [25:1214] se afiguraria pouco natural, mediante traços exagerados que põem em movimento a nossa imaginação. Por conseguinte, a Antropologia é necessária também aos escritores de romances e comédias. A Psicologia Empírica de Baumgarten é, em razão da sua ordem, o melhor fio condutor, [mas] apenas a ordem de matérias e capítulos [desta] será preservada nesta antropologia - embora muitas outras considerações coincidam -, na medida em que o livro deste visa apenas o escolástico.

Ora, resta ainda uma questão com respeito à aprendizagem da Antropologia a partir da experiência.

Quaestio[.] É mais difícil aprender a conhecer-se a si mesmo, ou à Humanidade? Responsio[.] Ambas têm as suas dificuldades. Ainda assim, é porém mais fácil aprender a conhecer-se a si mesmo e aos outros do que [conhecer] a Humanidade em geral; pois se eu quero aprender a conhecer-me a mim mesmo, basta que eu me compare com outros homens, mas a Humanidade, não posso eu compará-la com nenhuma outra criatura 
racional, pois nós somos a única sobre a Terra. No entanto, ambas têm para si as suas próprias dificuldades[.]

1. Observar-se a si mesmo parece ser fácil, pois [um indivíduo] tem-se sempre à mão e está mais consciente das suas molas propulsoras em cada acção; no entanto, isto é de facto difícil, pois as molas propulsoras da alma humana, as inclinações e as paixões, ou estão em <acção> movimento, ou em repouso. Se elas estiverem em movimento, não se pensa em observá-las; mas se elas estiverem em repouso, então a ocasião passou, e a capacidade para recordar está também já apagada, ou é incompleta. Para se conhecer a si mesmo é necessária uma série de observações, e isto é ainda mais difícil.

2. Observar outros é ainda mais difícil, pois os homens encobrem o seu verdadeiro carácter quando notam que estão a ser observados; e ninguém se quer deixar observar, e quanto mais civilizado for o homem, tanto mais ele se dissimula. Eles são corruptos. Mas conhecimento do género humano é, em geral, o mais difícil.

\section{VII. \\ ANTHROPOLOGIE-BUSOLT (1788/89)}

\section{Prolegomena.}

[25:1435] Faz-se uma distinção entre conhecimento de Escola e conhecimento do Mundo.

Conhecimento de Escola tem-se, quando se pode comunicar a outros o seu conhecimento segundo um certo sistema. Mas conhecimento do Mundo, tem-se quando se logra veicular a outros esse mesmo conhecimento em conversas ou sociedades, e isso de tal modo que se deixe de fora o pouco interessante e, porém, se seja suficientemente entendível, e por consequência agradável. Aquele que não lograr este último [pressuposto], designa-se por um pedante. De resto, um pedante pode ser um homem deveras hábil, apenas lhe falta o acima mencionado - - . Aquilo que mais nos ocupa no Mundo, que mais põe em movimento as nossas inclinações, os nossos apetites e a nossa vontade, é o Homem. Por conseguinte, conhecimento do Mundo é exactamente o mesmo que conhecimento do Homem. Ora, se esta observação dos homens (Antropografia) for usada como uma ciência, então ela designa-se por Antropologia. Esta ciência é alcançável: 
1.) Mediante a extensão e diversidade das experiências, e mediante viagens.

Anotações. Se se quiser reunir conhecimentos antropológicos mediante viagens, há que ter previamente um abundante e coerente conhecimento dos homens, para que, com um certo plano, e dadas as diferenças dos homens que lhe sejam dadas a ver mediante o viajar, se possa situar as suas observações.

2.) Quando se faz observações atentas de si mesmo e de outros homens. Um tal conhecimento dos homens é possível porque diariamente, nos nossos ofícios e nas sociedades, nos é dada ocasião de adquirir antropognosia. Se mediante experiências involuntárias e mediante observações adquirimos conhecimento dos homens, e se o mesmo for exposto em uma conexão, e segundo um certo método, ou, numa palavra, sistematicamente: então isso é uma ciência a que se pode chamar Antropologia.

Há 3 espécies de doutrinas.

1.) Temos de procurar adquirir habilidade, mediante ciências teoréticas [25:1436] que podem ser empregues a contento em qualquer obra

2.) Temos de nos esforçar por nos formarmos segundo o modo de pensar e as capacidades dos homens com os quais temos que ver, a fim de que não nos tornemos para estes nem demasiado graves, nem demasiado incómodos. Ora, isto nos ensina a Antropologia, que nos mostra como podemos usar os homens para o nosso fim. A regra de prudência é ensinada não na Escola, mas sim no conhecimento do Mundo.

3. A doutrina da sabedoria. Esta não conduz apenas a vantagens, antes [ensina] como mediante isto podemos dispensar forças da alma, coisas que não são necessárias, e alcançar a melhor escolha na nossa acção. Estas três espécies de doutrinas, podemos exprimi-las de um outro modo, e mais concisamente

1. Mediante a ciência da Escola, na qual somos cultivados.

2. Mediante a doutrina da prudência, na qual somos civilizados.

3. Mediante a doutrina da sabedoria, na qual aprendemos a estimar-nos a nós mesmos, ou onde vimos a ser moralizados.

Doutrinas que promovem a habilidade são práticas

------ Moral [Moral]------moral [moralisch]

------ Prudência---------Pragmática

Assim, a História é de grande utilidade e uma fonte da Antropologia, se for tratada pragmaticamente, a saber, de tal modo que eu extraia da História uma doutrina da prudência que me torne prudente e cauto com respeito à escolha das minhas acções, na qual eu aprenda cada vez melhor a conhecer a constituição do Homem. Uma tal antropologia pragmática é agora o nosso fim. Ela deve ser não uma antropologia teoética, que apenas 
esboça perguntas e apenas contém em si investigações psicológicas, antes queremos dar uma indicação como se pode conhecer a constituição do Homem mediante observação, a fim de aqui $a$ usarmos para o nosso fim. Uma outra pergunta poderia ainda ser formulada[:] se é possível que se crie uma Antropologia completa. Isso não é possível; pois o ânimo do Homem muito se pode dissimular. A Antropologia repousa sobre dados empíricos, que são dados a partir da experiência. Os últimos, adquirimo-los ou:

[25:1437] a.) mediante arte, e por certo

aa) mediante observação, quando observamos o objecto tanto quanto queremos.

Anotação[.] O Homem, porém, não quer ser observado. Pois logo que se atenta em alguém, e ele o nota: então ou ele se mostra constrangido, ou ele se dissimula. Em ambos os casos, o Homem não é aquele que inicialmente era. Por conseguinte, se se quer observar, então é necessário que não se seja notado.

bb.) Mediante experimentações. Mediante isto, tão-pouco pode o Homem ser observado. Pode-se perfeitamente fazer experimentações com animais e coisas; mas não com homens; pois assim que o homem nota isto, ele faz justamente o oposto daquilo que se quer ter. Assim note que eu o quero importunar, ele começará certamente a protestar.

b.) Mediante experiência em geral de outros.

Embora a Antropologia seja nisto incompleta, ela é porém indispensável e cria grande benefício.

1. Na arte de educar.

2. Em perspectiva à influência que temos uns sobre os outros. Em especial os detentores de poder, que em vista de um conhecimento dos homens apropriado podem lançar mãos à obra de modo completamente diferente[;] pois, com efeito, nem tudo pode ser alcançado mediante violência.

3. Em perspectiva à influência [desta] sobre Moral e Religião, pois, mediante estes conhecimentos, pode dar-se a estes deveres a força de molas propulsoras.

Esta característica (pois a Antropologia é verdadeiramente uma característica), com respeito ao seu método, divide-se nas [seguintes] doutrinas.

1. Do carácter das pessoas.

2. - -

3. ------------ dos povos.

4. -------- do género. 
É difícil conhecer a humanidade segundo todos os seus princípios; pois entre a humanidade e outros seres racionais não podemos estabelecer nenhuma comparação específica. É por isso uma importante circunstância, a da determinação do carácter da humanidade na Antropologia.

\section{VIII. ANTHROPOLOGIE-DOHNA ${ }^{29}$ (1790/91)}

\section{O conhecimento do Homem Introdução}

Desde sempre houve dois modos de estudar mediante os quais se era formado: 1. Escola. Ela torna(-nos) hábeis. A sua principal característica é suplantar outros em quantidade de ciência. Um tal erudito, designamo-lo por um escolástico. Ele pode fazer uso da sua erudição com utilidade, quando muito, enquanto homem de escola. Aquele que é ensinado pela escola é passivo. 2. Conhecimento do Mundo. Ele torna(-nos) astutos e prudentes, a fim de trazer a habilidade ao homem. Um homem do Mundo é jogador no grande jogo da vida.

Um pedante é um homem que não logra trazer a sua erudição ao homem, que não logra fazer disso nenhum uso conforme a fins, que é formado pela Escola, não pelo Mundo.

Pedantismo é afeição ao formal. Um pedante não passa nenhum tempo com mulheres, antes o emprega na ampliação dos seus conhecimentos.

A maior parte dos homens forma-se mediante a Escola para o Mundo, e é formada mediante o Mundo para o Mundo. Ambos unidos, 1. Conhecimento da Escola e 2. Formação mediante convívio, é o que faz melhor.

Homem do Mundo, diz-se do saber as relações com outros homens, e como se procede na vida humana.

Ter Mundo, diz-se de ter as máximas e de imitar grandes modelos. [A expressão] vem dos franceses. O fim, alcança-se mediante conduta, costumes, convívio, etc.

\footnotetext{
${ }^{29}$ I. Kant (1965), Die Philosophischen Hauptvorlesungen Immanuel Kants. Nach den neu aufgefundenen Kollegheften des Grafen Heinrich zu Dohna-Wundlacken, hrsg. Arnold Kowalewski, Hildesheim: Georg Olms Verlag, pp. 71-74. [n.d.t.]
} 
Pode-se ter muito Mundo e, porém, ser ignorante. O Mundo consiste em formalidades. Aqueles que para ele são por Natureza ineptos, esses não chegam a adquirir formação no Mundo, mas não obstante sabem apreciar tudo correctamente.

Pode-se trabalhar a Antropologia segundo um método duplo:

1. Em conformidade à Escola (escolasticamente), especulativamente, na medida em que ela nos dá a conhecer os homens como eles são. Esta é a [Antropologia] teorética (a psicologia [doutrina da alma] é uma tal Antropologia especulativa. Ela visa o interior.)

2. popular (pragmático), na medida em que ela nos é útil para poder fazer boa aplicação daquilo que se sabe. Nem sempre nos tornamos prudentes por experiência e por prejuízo [próprios]. Tenho ainda de receber regras que me advertem. Experiência torna-nos engenhosos. Toda a doutrina prática é: 1. técnica, doutrina da arte e da habilidade, ou 2. pragmática, doutrina da prudência, a fim de usar homens para os meus propósitos. Por exemplo, um relojoeiro que não alcança a última, que é rude, mas de resto é hábil na técnica, poucos proventos pode ter. Governar homens e máquinas, para isso é requerida uma espécie muito diferente de arte. A história pragmática torna os homens mais prudentes (mediante aplicações), a teorética não. Antropologia pragmática dá para a mão máximas [sobre] como se há-de proceder para com homens. Jovens teólogos têm de se esforçar não apenas por alcançar uma escolha sensata na vida prática, mas também por procurar trazê-la aos homens.

Quem quer conquistar homens, tem grandes dificuldades a suplantar. É também difícil, conhecer-se a si mesmo e aos outros. Se se quiser sondar a sua própria maneira de sentir, há que observar-se a si mesmo. Isto só pode ocorrer fugazmente, ou em retrospectiva, quando a maioria das impressões, sensações, etc., já feneceram. Nos idosos, as molas propulsoras que os governavam em jovens já feneceram. Daí que as acções irreflectidas que estes empreenderam em jovens se lhes afigurem incríveis. Observar-se em ira, ou em serenidade, seria contradição. A saber, há que estar sempre em um outro estado.

Um pintor dificilmente logra trazer um homem à vida; pois o pensamento: eu deixo-me pintar, produz a impressão de que se está como que pressionado, e os traços da face melindrados. Assim, o pintor só pode trazer à vida se a pessoa que ele pinta estiver distraída.

Dificilmente o Homem aprende a conhecer-se a si mesmo. Ao invés, observar outros é ofensivo. Para além disso, tem-se já o suficiente que fazer consigo mesmo. Apenas a descontento alguém se deixa observar. [O observado] logo o nota, dissimula-se, raramente é sincero, é amiúde 
afectado, excêntrico, e deixa-se ver sempre pelo [seu] melhor lado. Assim se passa, mais ou menos, com a maioria dos casamentos. Em festas, em sociedades, crê-se ver casamentos verdadeiramente paradisíacos. Assim são de fora. Mas, não raras vezes, são uma outra coisa por dentro.

Para além disso, há que pugnar por investigar:

1. o carácter do Homem, a saber, de diferentes pessoas individuais. Isto é possível conquanto cada homem se diferencia sempre do outro mediante certas particularidades. Ainda assim, isto é difícil. Ao mais pequeno detalhe, é aliás impossível.

2. o carácter da Humanidade em geral. $\mathrm{O}$ que o Homem é à parte, enquanto espécie, é ainda mais difícil de investigar do que o que precedeu. A pessoas individuais aplicam-se comparações, mas ao todo não.

No que diz respeito às fontes da Antropologia, tem-se por certo:

1. o viajar. Isto antes ensina a conhecer países e cidades, e não homens, o que requer que se tenha aprendido a reflectir sobre os homens [isto é, a familiarizar-se com observações que outros tenham já feito sobre os homens.]

2. O convivio com homens. Ele tem de ser popular, isto é, aberto. [Como se diz no Evangelho: prudente como as serpentes, e símplice como as pombas, o mesmo dizendo o provérbio volto sciolto \&]. Só mediante sinceridade, só mediante uma essência livre e alegre se pode alcançar o conhecimento do Homem. De outro modo, políticos nunca perscrutarão o sentido dos ministerii. Eles nada denunciam, mas tão-pouco adivinham. Todo o homem tem um impulso para se abrir, para despejar o que lhe vai no coração. [Quem não tem este sentimento, tem de ser ou um idiota, ou um mau homem.] Isto é [para ele] um bálsamo. Se este for abordado com sinceridade, eis que ele confia e volta a abrir-se. Um homem refinado parecerá sereno, mesmo perante o maior infortúnio no jogo do faraó - ele foge para o [seu] interior. Para o perscrutar, há que vê-lo em outra ocasião, em uma situação na qual ele não se comporte de modo retraído.

3. A História. Ela pressupõe já conhecimentos prévios de Antropologia.

4. Teatro e romances, se eles forem como ocorre no mundo real. Ideais como Grandison, Addison, etc., corrompem. Nas peças, o [seu] género é melhor, pois elas apresentam toda a espécie de situações e diferentes carácteres. Censura-se as Máximas de La Rochefoucauld por descrever este sempre o lado mau dos homens. A causa porque, por exemplo, avós amam mais os netos do que os seus filhos, indica-a ele assim: porque os seus próprios filhos desejam a morte destes, para deles herdarem, eles odeiam-nos, mas amam os seus netos, pois, pela mesma razão acima mencionada, estes desejam a morte dos seus pais, a saber, os filhos odiados dos seus avós. 


\section{IX. \\ ANTHROPOLOGIE-STARKE ${ }^{30}$ \\ (1790/91)}

\section{Introdução ao conhecimento do Homem e ao conhecimento do Mundo}

A vida do Homem tem duas divisões; na primeira, tem de se adquirir conhecimentos e habilidades, e na outra tem de se aplicar e empregar os mesmos; pois aprendemos não por nós mesmos, mas para o Mundo; por isso, o nosso conhecimento pode também ser dividido em conhecimento de Escola (que nos ensina a conhecer coisas) e em conhecimento do Mundo (isto é, conhecimento do Homem).

Ter Mundo, diz-se da adequabilidade para o convívio segundo o gosto. Conhecer o Mundo é, com efeito, mais fácil do que ter Mundo. Um pedante tem conhecimentos da Escola, também por certo conhecimento do Mundo, mas nunca Mundo. Pedantismo seria, pois, a inadequabilidade no gosto do convívio.

Conhecimento do Mundo pressupõe sempre conhecimento de Escola, e aplicar a habilidade do mesmo.

Antropologia, que não deve ser apenas conhecimento de Escola, mas também conhecimento do Mundo, pode ser tratada escolasticamente ou pragmaticamente. Escolasticamente tratada, a Antropologia mostra o que o Homem é; ao invés, pragmaticamente, como se pode usar os homens para os nossos propósitos. Daí que a nossa prudência consista na habilidade de usar os homens de um modo bom para os nossos propósitos.

O Homem que é formado, é cultivado mediante o conhecimento da Escola, civilizado mediante convívio com outros, e moralizado mediante a união das duas partes acima mencionadas.

O conhecimento do Homem é principalmente dificultado na medida em que, se as molas propulsoras estão em movimento, o Homem não pode nem observar-se a si mesmo, nem aferir observações sobre coisas fora de si. Muito menos se deixam fazer experimentações com os homens; pois, por exemplo, se se quisesse tentar trazer a imaginação ao mais elevado grau possível, assim se operariam as maiores disrupções no entendimento.

${ }^{30}$ N. T. Starke, Friedrich Christian (1831), Immanuel Kants Anweisung zur Menschen- und Weltkenntnis, Leipzig, Die Expedition des Europäischen Aufsehers, pp. 1-3. 
Para além disso, o conhecimento do Homem é especialmente dificultado mediante dissimulação ou retracção, e mediante simulação ou um certo fingimento do que não existe.

Mas conhecer toda a humanidade é ainda mais difícil, pois com efeito podemos comparar homens com homens, mas não toda a espécie humana com outros possíveis seres racionais.

Viagens não podem operar conhecimento do Homem, antes servem apenas para comparar os homens que já se conhece com outros. As fontes mais privilegiadas de conhecimento do Homem são: 1) o convívio com outros. 2) Peças. 3) Romances. 4) Faces e 5) História.

\section{Bibliografia}

Kant, Immanuel (1901ff.), Gesammelte Schriften. Hrsg. von der Königlich-Preussischen Akademie der Wissenschaften zu Berlin (Akademie-Ausgabe), Berlin: Georg Reimer. (AA)

Kant, Immanuel (1965), Die Philosophischen Hauptvorlesungen Immanuel Kants. Nach den neu aufgefundenen Kollegheften des Grafen Heinrich zu Dohna-Wundlacken, hrsg. Arnold Kowalewski, Hildesheim: Georg Olms Verlag.

Kant, Immanuel, The Cambridge Edition of the Works of Immanuel Kant, ed. Paul Guyer, Allen W. Wood, Cambridge: Cambridge University Press, $1998 \mathrm{ff}$.

Starke, Friedrich Christian (1831), Immanuel Kants Anweisung zur Menschenund Weltkenntnis, Leipzig, Die Expedition des Europäischen Aufsehers. 